$\begin{array}{cccc}S \text { sciendo } & \text { International Conference KNOWLEDGE-BASED ORGANIZATION } \\ \text { Vol. XXV } & \text { No } 1 & 2019\end{array}$

\title{
THE PREMISES OF THE APPEARANCE OF THE EDUCATION CONCEPT FOR SUSTAINABLE DEVELOPMENT
}

\author{
Elisabeta-Emilia HALMAGHI, Ruxandra MOȘTEANU \\ "Nicolae Bălcescu” Land Forces Academy, Sibiu, Romania \\ emmahalmaghi@gmail.com
}

\begin{abstract}
Paradoxically, the more educated and wealthier the society is, the greater the negative impact on the environment, because the consumption needs are higher, which leads to an increase in the pollution of the environmental factors. This leads us to the conclusion that, in order to achieve sustainable development, education of the population is not sufficient. The link between sustainable development and education is very complex, and the challenge faced by mankind is to educate the population to become a factor of change.
\end{abstract}

Keywords: sustainable development, education, environmental protection, resources, pollution

\section{Introduction}

Initially, sustainable development was intended to be a solution to preserve the quality of the environment as a result of the ecological crisis caused by the intensive exploitation of resources and the continuous degradation of the environment. In recent years, the concept promotes the idea of a balance between economic development, social equity, population education, people's living conditions, efficient use of natural resources and environmental preservation.

\section{Research methodology}

The paper addresses the issue of the emergence of the concept of education for sustainable development as a result of the increasing importance of education for society and that contributes to sustainable development. The concepts of sustainable development and education for sustainable development are presented and analyzed, based on the literature and direct observations, the latter being seen as an instrument in achieving sustainable development.

3. Premise of the emergence of the concept of sustainable development

In the early 1970s, scientists, as well as some politicians and businesspeople, began to alert the effects of economic growth and development on the environment. The increasingly heated discussions on economic and social development and on how the environment is affected have led to the organization of the first United Nations Conference on Human Environment in Stockholmin 1972. The debates resulted in a series of documents (the Stockholm Declaration, the Human Action Plan, etc.) and the establishment of environmental organizations. At the conference, it was agreed that there is a need to strike a balance between the economy, society and the environment. Although the concept of sustainable development stems from the discussions held at this conference, where the common nature of human activities and 
the environment has been officially recognized by the international community, it has been several years before this concept entered the usual vocabulary.

As there was little progress in integrating environmental protection into development policies, the World Commission on Environment and Development, also known as the Brundtland Commission, was established in 1983. In 1987, the commission published the Joint Future Report, which was to be the basis for the papers adopted at the Rio de Janeiro Summit in 1992 (Agenda 21 and the Rio Declaration). At the same time, the report would include the most well-known definition of sustainable development: "development that meets the needs of the present generation without compromising the ability of future generations to meet their own needs." The report acknowledges that the economic development of the world's states cannot be stopped, but that a change in development strategies is needed so that development can take place within the environmental limits of existing resources and without affecting the environmental factors. The report endorsed the need to organize an international conference on sustainable development.

In 1992, at the Earth Summit in Rio de Janeiro, the issue of the sustainable development of mankind was the head of the meeting poster and led to the initiation of the international cooperation process in the field of sustainable development and environmental issues. The most important document signed on this Summit was Agenda 21, a document through which the world's states committed themselves to promoting sustainability by any means, including through education.

\section{Education for Sustainable Development(ESD)- the key to a sustainable future}

In the 70's of the last century, in the literature, education was considered to have, among others, a decisive role in the achievement of a fair and worry-based society of environmental issues. Also, the Brundtland Report argued that teachers had an important role to play in making social change.

The concept of Sustainable Development Education (ESD) emerged when world leaders reached an agreement on the concept of sustainable development and the fact that it should be considered as a global goal. With the adoption of the concept of sustainable development, conceptual education was also approved, which supports sustainable development. Education for Sustainable Development aims to develop competencies that help people reflect on their own actions, taking into account the social, cultural, economic and environmental impacts. Education for Sustainable Development is an interdisciplinary approach to learning that covers the integrated social, economic and environmental dimensions of formal and informal curricula. This type of education was not initiated by education specialists, but came from international political and economic forums.

The first international document that considered education as a fundamental tool for achieving sustainable development and highlighted areas of action for education was Agenda 21 in Chapter 36 (Promoting Education, Public Awareness and Training). It was clearly stated in this chapter that the promotion of education, awareness and sensitization of people, vocational training are related to almost all areas of Agenda 21. This approach to the concepts of sustainable development and Education for Sustainable Development (ESD) drew attention to changes in the environmental issues. Agenda 21 led to the international recognition of the ESD and its importance in the implementation of sustainable development objectives.

The following Sustainable Development Summits - Johannesburg Earth Summit (2002), Rio +20 Earth Summit in Rio de Janeiro (2012) - emphasized the increasing 
importance of Education for Sustainable Development and turned it into a key factor in the sustainable development of society. The 2012 Earth Summit highlighted the commitment of governments in the world to promote Education for Sustainable Development by incorporating it into sustainable development. Sustainable development cannot be achieved through technology solutions, policy regulations or financial instruments. Education and learning are needed at all levels and in all social contexts. That is why Education for Sustainable Development has been a topic of discussion and on the agenda of other high-level international meetings where issues of economic development, the need to protect the environment, climate change, such as the Paris Agreement for climate change (2015), were discussed.

The United Nations Educational, Scientific and Cultural Organization (UNESCO) was elected to promote Education for Sustainable Development. The United Nations Decade of Education for Sustainable Development (2005-2014) aimed to integrate the principles and practice of sustainable development into all aspects of education and learning, encouraging changing attitudes towards the environment.

The United Nations Decade of Education for Sustainable Development was followed by the Global Action Program on Education for Sustainable Development endorsed by the UNESCO General Conference in November 2013 and recognized by UN General Assembly Resolution A/RES/ 69/211 of December 2014. The purpose of this program is to generate and expand Education for Sustainable Development. Current global issues - climate change, world economic development, population growth, resource depletion, etc. - require profound transformation of the way we think and the urgent change of life style. For a change to take place, new values and attitudes are needed. Education for Sustainable Development allows people to acquire and develop the knowledge, attitudes, values and abilities needed to make the most accurate decisions for improving the quality of life for a sustainable future.

In September 2015, the UN General Assembly adopted Agenda 2030 for Sustainable Development, in which the 17 Sustainable Development Objectives represent its essence. These goals aim to ensure a sustainable, peaceful, prosperous and fair life for all people. Sustainable Development Goals barriers to sustainable development are the following: inequality, unsustainable consumption patterns, weak institutional capacity, and environmental degradation.

Although Education for Sustainable Development is explicitly formulated as a stand-alone objective - Sustainable Development Objective $4-$ it is of particular importance for all other Sustainable Development Objectives as it enables people to contribute to sustainable development by changing their own behaviour and promoting change in the economic and political life of society. Education for Sustainable Development can produce specific cognitive, socio-emotional and learning outcomes that enable people to cope with the specific challenges of each Sustainable Development Goal, thereby facilitating their fulfilment. Education for Sustainable Development is both an end in itself and a means of achieving Sustainable Development Goals. This is not only an integral part of sustainable development; it is also an important factor for it and an essential strategy for achieving the Sustainable Development Goals.

The Global Action Program on Education for Sustainable Development aims to make an essential contribution to Agenda 2030 through two objectives:

a) reorienting education and learning so that each person has the opportunity to acquire knowledge, skills, values and attitudes that will help him/her to contribute to a sustainable future of mankind; 
b) enhancing education and learning in all actions, programs, meetings and activities that promote sustainable development.

\section{Conclusions}

Education for Sustainable Development is essential to achieving a sustainable society and can generate a change in people's mentalities, potentiating their ability to create a safer, healthier and more prosperous world, improving the quality of people's lives. Education for Sustainable Development leads to a reorientation of people's education towards motivating them

to become more responsive to the environmental, economic and social problems faced by mankind today.

Education for Sustainable Development contributes both to sustainable development and to the transformation of society. Sustainable development improves education and has the capacity to transform it. Education for Sustainable Development means more than teaching viable sustainability principles, it provides a coherent interaction between education and public awareness, helps social transformation, and aims at creating a sustainable society.

\section{References}

[1] Leicht, Alexander, Heiss, Julia and Byun, Won Jung (eds), Issues and trends in Education for Sustainable Development, UNESCO; 2018.

[2] Tilbury, Daniella, Stevenson, Robert B., Fien, John and Schreuder, Danie (eds.), Education and Sustainability: Responding to the Global Challenge, Commission on Education and Communication, IUCN, Gland, Switzerland, and Cambridge, U.K., 2002.

[3] Education for sustainable development, https://www.heacademy.ac.uk/knowledgehub/education-sustainable-development-0, accesed on 10.05.2019.

[4] Educația pentru dezvoltare. 17 obiective pentru a schimba lumea, 2015, https://www.academia.edu/23515040/Educatia_pentru_dezvoltare_durabila_RO_-

Education_for_sustainable_development, accessed on 15.04.2019.

[5] Educație pentru obiectivele dezvoltării durabile. Obiective de învățare, 2017, http://dezvoltaredurabila.gov.ro/web/wp-content/uploads/2017/12/manualUNESCO.pdf, accessed on 25.04.2019.

[6] ESD (Education for Sustainable Development)http://www.mext.go.jp/en/unesco/title04/detail04/sdetail04/1375695.htm, accesed on 10.05.2019.

[7] What is Education for Sustainable Development?, https://www.plymouth.ac.uk/students-and-family/sustainability/sustainabilityeducation/esd, accesed on 12.05.2019. 